\title{
KERAPATAN DAN VIABILITAS SPORA BEAUVERIA BASSIANA (BALS.) AKIBAT SUBKULTUR DAN PENGAYAAN MEDIA, SERTA VIRULENSINYA TERHADAP LARVA PLUTELLA XYLOSTELLA (LINN.)
}

\author{
Siti Herlinda ${ }^{1}$, Muhamad Darma Utama ${ }^{1}$, Yulia Pujiastuti ${ }^{1}$, dan Suwandi ${ }^{1}$
}

\begin{abstract}
Density and viability of spores of Beauveria bassiana (Bals.) Vuill. due to sub-cultures and media enriched, and its virulence against larvae of Plutella xylostella (Linn.) This laboratory research was conducted to determine density and viability of spores of Beauveria bassiana due to sub-cultures and media enriched, and to investigate the fungi virulence againts larvae of Plutella xylostella. B. bassiana was grown in Saborroud Dextrose Broth (SDB) cultures enriched with cricket powder. The results showed that the best sub-culture was the fourth sub-culture enriched with cricket powder, producing $6.05 \times 10^{8}$ spores $/ \mathrm{ml}$ with $30.7 \%$ viability. The highest larval mortality was found in the second sub-culture enriched with cricket powder which was reach $78.33 \%$. The spore density and viability, and virulence of $B$. bassiana grown in sub-culture without cricket powder enrichment was consistently decreasing from the second sub-culture to the eighth. Sub-cultures enriched with cricket powder could increase density, viability, and virulence of B. bassiana in every sub-culture. Overall, the enrichment with cricket powder up to $0.5 \%$ could increase the density, viability, and virulence of B. bassiana.
\end{abstract}

Key words: sub-cultures, Beauveria bassiana, Plutella xylostella

\section{PENDAHULUAN}

Beauveria bassiana (Bals.) (Vuill.) (Deuteromycetes: Moniliaceae) adalah salah satu jamur entomopatogenik yang berpotensi untuk dikembangkan sebagai agens pengendali hayati. $B$. bassiana sangat efektif dalam menekan perkembangan larva Lepidoptera (Suharto et al., 1998; Soetopo, 2004). Jamur ini belum pernah dilaporkan resisten terhadap serangga hama (Utomo et al., 1998; Wahyudi, 2002), namun dalam perbanyakannya secara in vitro banyak kendala yang harus diatasi, seperti penurunan kualitas spora (kerapatan dan viabilitas) dan virulensi.

Penurunan kualitas spora dan virulensi B. bassiana dapat terjadi selama proses subkultur in vitro. Subkultur lebih dari lima generasi secara nyata dapat menurunkan kerapatan spora jamur entomopatogenik, seperti Metarhizium anisopliae (Taborsky, 1997). Viabilitas spora dapat menurun apabila selama subkultur terjadi penurunan sumber karbon, seperti glukosa, glukosamin, khitin, pati, nitrogen untuk hifa tumbuh (Tanada \& Kaya, 1993). Selain itu, kurangnya asupan protein dari media biakan dapat menurunkan kemampuan spora berkecambah (Rosalind, 2000). Dengan demikian, subkultur berulang dan nutrisi media biakan dapat menurunkan kualitas spora dan virulensi jamur entomopatogenik. Selama ini belum pernah dilaporkan pengaruh subkultur dan pengayaan media terhadap kualitas spora dan virulensi $B$. bassiana. Oleh karena itu, tulisan ini melaporkan tentang pengaruh subkultur dan pengayaan media terhadap kerapatan dan viabilitas B. bassiana, serta virulensinya terhadap larva Plutella xylostella (Linn.) (Lepidoptera: Yponomeutidae).

\section{METODE PENELITIAN}

Penelitian ini dilaksanakan di Laboratorium Entomologi, Jurusan Hama dan Penyakit Tumbuhan, Fakultas Pertanian, Universitas Sriwijaya, Inderalaya, Sumatera Selatan sejak bulan September 2003 sampai Maret 2004. Suhu rata-rata selama penelitian adalah $24,2^{\circ} \mathrm{C}$ dengan kelembaban nisbi $78,60 \%$.

Penyediaan Koloni $P$. xylostella. Larva $P$. xylostella dikumpulkan dari pertanaman caisin di Kenten, Palembang. Kemudian larva dibawa ke laboratorium dan dipelihara dalam wadah plastik (diameter $30 \mathrm{~cm}$ dan tinggi $35 \mathrm{~cm}$ ) yang bagian tutupnya terbuat dari kain kasa. Ke dalam wadah plastik dimasukkan tanaman caisin yang ditanam dalam pot plastik (diameter $15 \mathrm{~cm}$ dan tinggi $20 \mathrm{~cm}$ ) untuk pakan larva $P$. xylostella. Setiap hari kepompong dikumpulkan dan dimasukkan ke dalam kurungan kasa (panjang 50

\footnotetext{
${ }^{1}$ Dosen Jurusan Hama dan Penyakit Tumbuhan, Faperta Universitas Sriwijaya

Kampus Inderalaya Ogan Ilir Inderalaya 30662, email: linda_hasbi@pps.unsri.ac.id
} 
$\mathrm{cm}$, lebar $50 \mathrm{~cm}$, dan tinggi $50 \mathrm{~cm}$ ). Setelah imago terbentuk, ke dalam kurungan dimasukkan tanaman caisin untuk tempat peletakan telur. Larva dari telur yang menetas dipindahkan ke dalam wadah plastik $(34 \mathrm{~cm} \times 26 \mathrm{~cm} \times 7 \mathrm{~cm})$ yang berisi daun caisin. Larva-larva yang digunakan untuk perlakuan adalah keturunan kedua (F2) atau setelahnya.

Penyediaan Isolat-isolat $\boldsymbol{B}$. bassiana. Tiga isolat $B$. bassiana diperoleh dari berbagai jenis serangga inang dan lokasi (Tabel 1). Pembiakan isolat sebagai sumber inokulum dilakukan dengan menumbuhkan miselium dari serangga yang mati karena $B$. bassiana pada media GYA (Glucose Yeast Agar) dengan komposisi per liter media adalah glukosa $10 \mathrm{~g}$, agar $20 \mathrm{~g}$ dan ragi instan $4 \mathrm{~g}$ pada cawan petri dan diinkubasi pada suhu kamar yang ditambah dengan tepung jangkrik (Gryllotalpa americana Pal.). Tepung jangkrik diperoleh dengan memanaskan 100 ekor imago jangkrik hidup pada suhu $100^{\circ} \mathrm{C}$ selama 3 jam. Jangkrik selanjutnya ditumbuk sehingga menjadi tepung ukuran lolos saringan $1 \mathrm{~mm}$.

Pengamatan Kerapatan dan Viabilitas Spora B. bassiana Akibat Subkultur. Kerapatan dan viabilitas spora $B$. bassiana pada media SDB (Saborroud Dextrose Broth) akibat subkultur dikaji berdasarkan kebugaran spora yang dihasilkan dari II, IV, VI dan VIII generasi subkultur.

Spora subkultur (generasi keturunan) 0 pada media cair adalah spora yang diperoleh dari B. bassiana yang dibiakan dari media GYA di atas. Generasi subkultur I diperoleh dengan cara membiakkan spora B. bassiana dari media GYA ke SDB. Spora diambil dengan menggunakan jarum ose. Kemudian dilarutkan ke dalam air steril dalam tabung reaksi steril (ukuran $10 \mathrm{ml}$ ) dan dikocok dengan shaker (kecepatan 470 osilasi/menit) hingga tercampur merata $( \pm 10$ menit). Lalu dilakukan pengenceran sehingga didapatkan suspensi dengan kerapatan spora $10^{6} / \mathrm{ml}$. Sebanyak $0,5 \mathrm{ml}$ suspensi tersebut dituangkan ke dalam tabung reaksi (berukuran volume $10 \mathrm{ml}$ ) yang telah berisi $4,5 \mathrm{ml}$ media SDB dan tepung jangkrik. Komposisi tepung jangkrik yang telah disterilkan di dalam autoklaf selama 15 menit dan digunakan untuk setiap perlakuan, yaitu 0 (= tanpa tepung jangkrik), $0,2 \%$, $0,5 \%$, dan $1 \%$ (komposisi $30 \mathrm{~g} / \mathrm{l}$ air steril). Setelah itu, suspensi diinkubasikan selama 7 hari sambil terus dikocok dengan shaker pada posisi dengan kemiringan $30^{\circ}$. Hasil dari tahapan ini merupakan generasi subkultur I. Untuk mendapatkan generasi subkultur II dengan cara menginfestasikan kembali B. bassiana hasil dari subkultur I pada media SDB dengan cara kerja yang sama seperti cara kerja pembuatan subkultur I, begitu juga dengan subkultur berikutnya.

Penentuan kerapatan spora dengan cara suspensi spora dari perlakuan perbanyakan isolat diambil sebanyak $1 \mathrm{ml}$ kemudian dengan menggunakan hemasitometer yang telah ditetesi suspensi tersebut dihitung kerapatan sporanya di bawah mikroskop binokuler dengan perbesaran 400 kali.

Kerapatan spora dihitung dengan menggunakan rumus Gabriel \& Riyatno (1989) sebagai berikut:

$$
\mathrm{C}=\frac{\mathrm{t}}{(\mathrm{n} \times 0,25)} \times 10^{6}
$$

Keterangan :

C : kerapatan spora per ml larutan

$\mathrm{t} \quad$ : jumlah total spora dalam kotak sampel yang diamati

$\mathrm{N}$ : jumlah kotak sampel (5 kotak besar x 16 kotak kecil)

0,25 : faktor koreksi penggunaan kotak sampel skala kecil pada hemasitometer.

Viabilitas spora ditentukan dengan cara suspensi spora diinkubasikan selama 24 jam. Setelah itu satu tetes suspensi tersebut diteteskan pada kaca preparat dan ditutup dengan gelas penutup, lalu dihitung jumlah spora-spora yang berkecambah dan tidak berkecambah pada bidang pandang di bawah mikroskop dengan perbesaran 400 kali. Penghitungan

Tabel 1. Isolat-isolat B. bassiana asal berbagai inang dan lokasi

\begin{tabular}{ccc}
\hline Kode isolat & Asal serangga inang & Daerah asal \\
\hline $\mathrm{PD}_{1}$ & P.xylostella & Pagaralam \\
$\mathrm{PD}_{2}$ & Chrysodeixis chalcites & Pagaralam \\
$\mathrm{WC}$ & Nilaparvata lugens & Bogor \\
\hline
\end{tabular}


viabilitas spora dilakukan pada jam ke-24 setelah inkubasi. Viabilitas spora dihitung dengan menggunakan rumus Gabriel \& Riyatno (1989) sebagai berikut:

$$
\mathrm{V}=\frac{\mathrm{g}}{(\mathrm{g}+\mathrm{u})} \times 100 \%
$$

Keterangan :

$\mathrm{V}$ : perkecambahan spora (viabilitas)

$\mathrm{g}$ : jumlah spora yang berkecambah

$\mathrm{u}$ : jumlah spora yang tidak berkecambah

Percobaan yang menggunakan media tanpa tepung jangkrik dilakukan dalam rancangan Split-plot dengan petak utama subkultur yang terdiri dari 4 taraf, yakni subkultur II, IV, VI, VIII dan anak-petak isolat terdiri dari 3 taraf, yaitu isolat $\mathrm{PD}_{1}, \mathrm{PD}_{2}, \mathrm{WC}$. Percobaan yang menggunakan media yang ditambahkan tepung jangkrik dilakukan dalam rancangan Split-Split-Plot dengan petak utama subkultur terdiri dari 4 taraf, yakni subkultur II, IV, VI, VIII, anak-petak isolat terdiri dari 3 taraf : isolat $\mathrm{PD}_{1}, \mathrm{PD}_{2}$, WC dan anak-anak-petak penambahan tepung jangkrik terdiri dari 4 taraf : $0 \%, 0,2 \%, 0,5 \%$, $1 \%$. Pengujian diulang sebanyak 3 kali.

Uji Virulensi B. bassiana yang Telah Disubkultur. Virulensi spora pada masing-masing generasi subkultur diuji dengan cara meneteskan $10 \mu$ suspensi (kerapatan $1 \times 10^{6} \mathrm{spora} / \mathrm{ml}$ ) pada larva $P$. xylostella instar ketiga. Setiap generasi spora diinokulasi pada 20 larva uji. Kemudian larva tersebut dipelihara dalam gelas plastik (diameter $8,5 \mathrm{~cm}$ dan tinggi $10 \mathrm{~cm}$ ) yang ditutup kain gas dan diberi pakan caisin.

Parameter virulensi yang diamati adalah mortalitas larva dan persentasi imago mucul. Pengamatan dilakukan setiap hari sampai larva uji menjadi imago. Mortalitas larva dihitung berdasarkan rumus Prijono (1989), sebagai berikut:

$$
\text { Persentase larva yang mati }=\frac{\sum \text { larva mati }}{\sum \text { seluruh larva }} \times 100 \%
$$

Pengamatan dilakukan setiap hari sampai larva uji menjadi pupa Pengujian data hasil pengamatan ini disusun dalam rancangan percobaan yang sama dengan rancangan untuk parameter kerapatan dan viabilitas spora.

Analisis Data. Data kerapatan spora dan viabilitas spora $B$. bassiana, dan mortalitas larva $P$. xylostella dianalisis menggunakan ANOVA dengan terlebih dahulu di transformasikan ke logaritma 10 untuk data kerapatan spora. Data-data pengamatan tersebut diuji kelayakan melalui asumsi analisis ragam menggunakan uji normalitas D'Agostino-Pearson Omnibus dan kehomogenan ragam Brown dan Forsythe (Fernandez, 2000). Jika kombinasi perlakuan menunjukkan pengaruh yang signifikan, maka analisis dilanjutkan dengan uji beda rata-rata dengan uji beda nyata jujur (BNJ) Tukey pada taraf uji 5\%. Pengolahan data menggunakan bantuan program SAS-STAT pada SAS 6.12 (Fernandez, 2000).

\section{HASIL DAN PEMBAHASAN}

\section{Hasil}

Kerapatan Spora B. bassiana. Kerapatan spora B. bassiana pada media SDB terus menurun bila subkultur terus dilakukan (Tabel 2). Penurunan kerapatan akibat subkultur tidak dapat dihambat pada media SDB yang tidak diperkaya dengan tepung jangkrik, namun pada media yang ditambah tepung jangkrik terjadi peningkatan kerapatan spora B. bassiana pada subkultur keempat.

Isolat juga mempengaruhi kerapatan spora B. bassiana (Tabel 3). Pada media SDB tanpa pemberian tepung jangkrik, isolat yang diisolasi dari larva P. xylostella $\left(\mathrm{PD}_{1}\right)$ mampu menghasilkan spora terbanyak. Pemberian tepung jangkrik pada media SDB dapat meningkatkan kerapatan spora. Isolat yang diisolasi dari larva $C$. chalcites $\left(\mathrm{PD}_{2}\right)$ paling peka terhadap pemberian tepung jangkrik karena kerapatan sporanya meningkat paling tinggi, dari 4,69 × $10^{8}$ menjadi $5,84 \times 10^{8}$ spora $/ \mathrm{ml}$.

Walaupun tepung jangkrik dapat meningkatkan kerapatan spora, namun pada konsentrasi yang terlalu tinggi justru menghambat pembentukan spora. Konsentrasi tepung jangkrik optimum yang dapat meningkatkan kerapatan spora adalah $0,5 \%$, lebih dari itu (1\%) kerapatan spora akan menurun (Tabel 4).

Viabilitas Spora B. bassiana. Subkultur secara nyata dapat menurunkan viabilitas spora $B$. bassiana yang dibiakkan hanya pada media SDB saja, namun 
Tabel 2. Kerapatan spora B. bassiana akibat subkultur yang diberi dan tanpa tepung jangkrik

\begin{tabular}{ccc}
\hline Subkultur & \multicolumn{2}{c}{ Rata-rata kerapatan spora $\left(10^{8}\right.$ spora/ml $)$} \\
\cline { 2 - 3 } & Diberi tepung jangkrik & Tanpa tepung jangkrik \\
\hline II & $5,59(8,73) \mathrm{b}$ & $5,26(7,20) \mathrm{a}$ \\
IV & $6,05(8,76) \mathrm{a}$ & $4,96(6,90) \mathrm{b}$ \\
VI & $4,96(8,67) \mathrm{c}$ & $4,12(7,61) \mathrm{c}$ \\
VIII & $3,64(8,53) \mathrm{d}$ & $3,20(7,50) \mathrm{d}$ \\
\hline
\end{tabular}


adalah hasil transformasi log (Y).

Tabel 3. Kerapatan spora tiga isolat B. bassiana akibat subkultur yang diberi dan tanpa tepung jangkrik

\begin{tabular}{ccc}
\hline Kode isolat & \multicolumn{2}{c}{ Rata-rata kerapatan spora $\left(10^{8}\right.$ spora/ml $)$} \\
\cline { 2 - 3 } & Diberi tepung jangkrik & Tanpa tepung jangkrik \\
\hline $\mathrm{PD}_{1}$ & $5,23(8,70) \mathrm{b}$ & $4,98(7,64) \mathrm{a}$ \\
$\mathrm{PD}_{2}$ & $5,84(9,74) \mathrm{a}$ & $4,69(7,60) \mathrm{b}$ \\
$\mathrm{WC}$ & $4,11(8,59) \mathrm{c}$ & $3,48(7,55) \mathrm{c}$ \\
\hline
\end{tabular}

Angka dalam lajur yang diikuti oleh huruf yang sama, tidak berbeda nyata (BNJ, $\mathrm{P}<0,05)$; angka dalam kurung adalah hasil transformasi $\log (\mathrm{Y})$.

penambahan tepung jangkrik pada media tersebut justru meningkatkan viabilitas pada subkultur keempat tetapi pada subkultur berikutnya kembali terjadi penurunan viabilitas (Tabel 5).

Isolat $\mathrm{PD}_{1}$ yang dibiakkan pada media $\mathrm{SDB}$ tanpa tepung jangkrik memiliki viabilitas spora paling tinggi dibandingkan isolat lainnya (Tabel 6). Viabilitas spora meningkat bila media SDB diberi tepung jangkrik. Peningkatan viabilitas paling tinggi terjadi pada isolat $\mathrm{PD}_{2}$.

Semakin tinggi konsentrasi tepung jangkrik cenderung menyebabkan peningkatan viabilitas spora, namun konsentrasi tepung jangkrik lebih dari 0,5\% justru semakin menurunkan viabilitas spora (Tabel 7). Viabilitas spora B. bassiana paling tinggi ditemukan pada media yang diberi tepung jangkrik $0,5 \%$ $(37,93 \%)$.

Virulensi B. bassiana. Subkultur tidak nyata mempengaruhi virulensi $B$. bassiana yang dibiakkan pada media SDB tanpa tepung jangkrik tetapi berpengaruh nyata bila $B$. bassiana tersebut dibiakkan pada media SDB yang diberi tepung jangkrik (Tabel 8). Penambahan tepung jangkrik pada media SDB meningkatkan virulensi $B$. bassiana. Tingkat mortalitas larva akibat $B$. bassiana subkultur kedelapan $(54,02 \%)$ yang diberi tepung jangkrik mendekati tingkat mortalitas larva $P$. xylostella akibat $B$. bassiana subkultur pertama yang tidak diberi tepung jangkrik $(51,11 \%)$. Virulensi paling tinggi ditemukan pada subkultur kedua yang menyebabkan mortalitas larva hingga $78,33 \%$, setelah itu virulensi terus menurun.

Semua isolat $B$. bassiana yang dibiakkan pada media SDB yang tanpa pemberian tepung jangkrik tidak nyata mempengaruhi mortalitas larva (Tabel 9). Isolat $\mathrm{PD}_{1}$ dan $\mathrm{PD}_{2}$ yang dibiakkan pada media $\mathrm{SDB}$ dengan pemberian tepung jangkrik dapat meningkatkan mortalitas larva $P$. xylostella masingmasing menjadi 69,47 dan 71,97\%.

Tepung jangkrik dapat meningkatkan virulensi B. bassiana. Konsentrasi tepung jangkrik yang optimum diberikan pada media pembiakkan B. bassiana adalah $0,5 \%$ karena pada konsentrasi 
Tabel 4. Kerapatan spora B. bassiana akibat subkultur yang diberi berbagai konsentrasi tepung jangkrik

\begin{tabular}{cc}
\hline Konsentrasi tepung jangkrik $(\%)$ & Rata-rata kerapatan spora $\left(10^{8}\right.$ spora/ml $)$ \\
\hline 0 (kontrol) & $4,38(8,63) \mathrm{c}$ \\
0,2 & $5,30(8,70) \mathrm{b}$ \\
0,5 & $7,01(8,84) \mathrm{a}$ \\
1,0 & $3,56(8,53) \mathrm{d}$ \\
\hline
\end{tabular}

Angka dalam lajur yang diikuti oleh huruf yang sama, tidak berbeda nyata (BNJ, P $<0,05)$; angka dalam kurung adalah hasil transformasi $\log (\mathrm{Y})$.

Tabel 5. Viabilitas spora B. bassiana akibat subkultur yang diberi dan tanpa tepung jangkrik

\begin{tabular}{ccc}
\hline Subkultur & \multicolumn{2}{c}{ Rata-rata viabilitas spora $(\%)$} \\
\cline { 2 - 3 } & Diberi tepung jangkrik & Tanpa tepung jangkrik \\
\hline II & $27,36(1,40) \mathrm{b}$ & $24,44(1,37) \mathrm{a}$ \\
IV & $30,70(1,44) \mathrm{a}$ & $22,78(1,34) \mathrm{b}$ \\
VI & $23,31(1,31) \mathrm{c}$ & $16,17(1,20) \mathrm{c}$ \\
VIII & $15,51(1,16) \mathrm{d}$ & $12,28(1,09) \mathrm{d}$ \\
\hline
\end{tabular}

Angka dalam lajur yang diikuti oleh huruf yang sama, tidak berbeda nyata (BNJ, $\mathrm{P}<0,05)$; angka dalam kurung adalah hasil transformasi $\log (\mathrm{Y})$.

Tabel 6. Viabilitas spora tiga isolat B. bassiana akibat subkultur yang diberi dan tanpa tepung jangkrik

\begin{tabular}{ccc}
\hline Kode isolat & \multicolumn{2}{c}{ Rata-rata viabilitas spora $(\%)$} \\
\cline { 2 - 3 } & Diberi tepung jangkrik & Tanpa tepung jangkrik \\
\hline $\mathrm{PD}_{1}$ & $25,21(1,36) \mathrm{b}$ & $23,33(1,41) \mathrm{a}$ \\
$\mathrm{PD}_{2}$ & $29,90(1,42) \mathrm{a}$ & $20,08(1,34) \mathrm{b}$ \\
$\mathrm{WC}$ & $17,55(1,21) \mathrm{c}$ & $13,33(1,28) \mathrm{c}$ \\
\hline
\end{tabular}

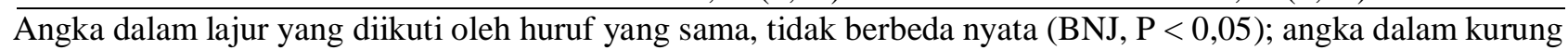
adalah hasil transformasi $\log (\mathrm{Y})$.

Tabel 7. Viabilitas spora B. bassiana akibat subkultur yang diberi berbagai konsentrasi tepung jangkrik

\begin{tabular}{cc}
\hline Konsentrasi tepung jangkrik (\%) & Rata-rata viabilitas spora $(\%)$ \\
\hline 0 (kontrol) & $18,91(1,25) \mathrm{c}$ \\
0,2 & $25,79(1,37) \mathrm{a}$ \\
0,5 & $37,93(1,56) \mathrm{b}$ \\
1,0 & $14,26(1,14) \mathrm{d}$ \\
\hline
\end{tabular}

Angka dalam lajur yang diikuti oleh huruf yang sama, tidak berbeda nyata (BNJ, $\mathrm{P}<0,05)$; angka dalam kurung adalah hasil transformasi $\log (\mathrm{Y})$. 
Tabel 8. Mortalitas larva P. xylostella yang diinfeksikan B. bassiana yang telah disubkulturkan dengan diberi dan tanpa tepung jangkrik

\begin{tabular}{ccc}
\hline Subkultur & \multicolumn{2}{c}{ Rata-rata mortalitas larva (\%) } \\
\cline { 2 - 3 } & Diberi tepung jangkrik & Tanpa tepung jangkrik \\
\hline II & $78,33(62,52) \mathrm{a}$ & $51,11(40,92) \mathrm{a}$ \\
IV & $74,86(60,05) \mathrm{b}$ & $48,89(39,38) \mathrm{a}$ \\
VI & $68,75(56,16) \mathrm{c}$ & $44,44(36,63) \mathrm{a}$ \\
VIII & $54,02(47,33) \mathrm{d}$ & $35,00(31,05) \mathrm{a}$ \\
\hline
\end{tabular}

Angka dalam lajur yang diikuti oleh huruf yang sama, tidak berbeda nyata (BNJ, P < 0,05); angka dalam kurung adalah hasil transformasi $\log (\mathrm{Y})$.

Tabel 9. Mortalitas larva P. xylostella yang diinfeksikan tiga isolat B. bassiana yang telah disubkulturkan dengan diberi dan tanpa tepung jangkrik

\begin{tabular}{ccc}
\hline Kode isolat & \multicolumn{2}{c}{ Rata-rata mortalitas larva $(\%)$} \\
\cline { 2 - 3 } & Diberi tepung jangkrik & Tanpa tepung jangkrik \\
\hline $\mathrm{PD}_{1}$ & $69,47(56,80) \mathrm{a}$ & $45,00(37,08) \mathrm{a}$ \\
$\mathrm{PD}_{2}$ & $71,97(58,50) \mathrm{a}$ & $46,25(37,91) \mathrm{a}$ \\
$\mathrm{WC}$ & $65,52(54,25) \mathrm{b}$ & $43,33(36,00) \mathrm{a}$ \\
\hline
\end{tabular}

Angka dalam lajur yang diikuti oleh huruf yang sama, tidak berbeda nyata (BNJ, $\mathrm{P}<0,05)$; angka dalam kurung adalah hasil transformasi $\log (\mathrm{Y})$.

tersebut mortalitas larva $P$. xylostella oleh jamur ini paling tinggi $(75,13 \%)$ (Tabel 10$)$.

\section{Pembahasan}

Kerapatan spora $B$. bassiana pada media SDB yang tidak diperkaya dengan tepung jangkrik terus menurun bila subkultur terus dilakukan, namun pada media yang ditambah tepung jangkrik terjadi peningkatan kerapatan spora $B$. bassiana pada subkultur keempat. Peningkatan kerapatan spora ini disebabkan media SDB yang ditambah tepung jangkrik cenderung lebih kental sehingga pertumbuhan miselia tertekan dalam kondisi demikian jamur lebih banyak memproduksi spora. Rasminah et al. (1997) melaporkan pada media biakan yang lebih padat, pertumbuhan miselia cenderung tertekan dan akibatnya lebih banyak spora yang diproduksi.

Isolat yang diisolasi dari larva C. chalcites $\left(\mathrm{PD}_{2}\right)$ paling peka terhadap pemberian tepung jangkrik karena kerapatan sporanya meningkat paling tinggi. Hal ini disebabkan isolat $\mathrm{PD}_{2}$ lebih mampu dalam memanfaatkan nutrisi pada media SDB sehingga produksi sporanya semakin meningkat. Taborsky (1997) melaporkan bahwa setiap isolat cenderung memiliki kemampuan yang berbeda dalam memanfaatkan nutrisi yang ada.
Penambahan tepung jangkrik pada media SDB selama subkultur dapat meningkatkan kerapatan spora B. bassiana hingga pada konsentrasi optimum $0,5 \%$. Semakin tinggi konsentrasi tepung jangkrik, semakin kental pula media dan semakin tertekan produksi miselia sehingga produksi spora meningkat, namun pada konsentrasi yang terlalu tinggi (1\%), penambahan tepung jangkrik justru menghambat pembentukan spora. Hal ini disebabkan konsentrasi yang terlalu tinggi ini yang melampaui dari kebutuhannya berakibat terjadi penumpukan metabolit yang dapat menghambat pembentukan spora. Alberts et al. (1994) menyatakan terjadinya penumpukan hasil metabolisme dari sintesis protein justru memacu terbentuknya enzim yang dapat menghambat metabolisme reproduksi jamur.

Subkultur secara nyata dapat menurunkan viabilitas spora $B$. bassiana yang dibiakkan hanya pada media SDB yang tanpa diperkaya dengan tepung jangkrik. Semakin banyak subkultur, semakin turun viabilitas spora B. bassiana. Hal ini terjadi karena energi yang tersimpan di dalam spora semakin rendah dengan semakin seringnya subkultur dilakukan. Penurunan energi yang dimiliki spora ini disebabkan kandungan nutrisi media SDB berupa khitin dan protein sangat rendah (Tabel 11). Khitin dan protein merupakan sumber energi yang banyak terdapat pada 
Tabel 10. Mortalitas larva P. xylostella yang diinfeksikan B. bassiana yang telah disubkulturkan dengan diberi berbagai konsentrasi tepung jangkrik

\begin{tabular}{cc}
\hline Konsentrasi tepung jangkrik (\%) & Rata-rata mortalitas larva (\%) \\
\hline 0 (kontrol) & $66,52(54,90) \mathrm{c}$ \\
0,2 & $70,55(57,47) \mathrm{b}$ \\
0,5 & $75,13(60,49) \mathrm{a}$ \\
1,0 & $63,75(53,21) \mathrm{d}$ \\
\hline
\end{tabular}

Angka dalam lajur yang diikuti oleh huruf yang sama, tidak berbeda nyata (BNJ, P < 0,05); angka dalam kurung adalah hasil transformasi $\log (\mathrm{Y})$.

Tabel 11. Kadar glukosa dan protein pada tepung jangkrik dan media SDB

\begin{tabular}{lccc}
\hline Jenis bahan & Volume & Protein $(\%)$ & Glukosa (\%) \\
\hline SDB & $100 \mathrm{ml}$ & 0,72 & 2,42 \\
Tepung jangkrik* & $100 \mathrm{~g}$ & 54,12 & - \\
\hline
\end{tabular}

" berat basah berkadar air $7,12 \%$.

integumen serangga. Dengan demikian, adanya penambahan zat-zat tersebut dapat menghambat penurunan viabilitas. Magan (2001) menyatakan spora yang terus-menerus dibiakkan pada media buatan yang kandungan nutrisi sangat berbeda dengan serangga inangnya cenderung akan menurun viabilitasnya.

Selama dilakukan subkultur, spora semua isolat yang dibiakkan pada media SDB dapat meningkat viabilitasnya bila media diberi tepung jangkrik. Semakin tinggi konsentrasi tepung jangkrik cenderung menyebabkan peningkatan viabilitas spora, namun konsentrasi tepung jangkrik yang optimun adalah $0,5 \%$. Peningkatan viabilitas setelah penambahan tepung jangkrik karena terjadi peningkatan konsentrasi protein yang tinggi pada media. Dari hasil analisis senyawa kimia menunjukkan kadar protein tepung jangkrik mencapai $54,12 \%$ per $100 \mathrm{~g}$ berat basah. Tanpa diberi tepung jangkrik, media SDB hanya mengandung $2,42 \%$ protein per $100 \mathrm{ml}$ media (Tabel 11). Hal ini membuktikan bahwa media SDB yang telah ditambah tepung jangkrik lebih banyak mengandung protein sehingga dapat meningkatkan viabilitas spora B. bassiana. Rosalind (2000) melaporkan kurangnya asupan protein dari media biakan dapat menurunkan kemampuan spora berkecambah sehingga viabilitas pun menurun. Selain itu, tepung jangkrik mengandung khitin yang sumber nutrisi yang lebih mirip nutrisi serangga inang alami sehingga lebih sesuai bagi perkembangan B. bassiana, sedangkan media SDB tanpa tepung jangkrik merupakan media yang tidak mengandung khitin. Tanada \& Kaya (1993) melaporkan bahwa khitin berguna untuk pertumbuhan hifa $B$. bassiana. Dengan demikian, peningkatan viabilitas spora B. bassiana dapat terjadi bila media pembiakan mengandung protein dan khitin.

Selama dilakukan subkultur, virulensi B. bassiana yang dibiakkan pada media SDB tanpa tepung jangkrik cenderung lebih rendah dibandingkan pada media SDB yang diperkaya dengan tepung jangkrik. Fenomena ini erat kaitannya dengan viabilitas spora $B$. bassiana, viabilitas spora lebih rendah pada media SDB tanpa penambahan tepung jangkrik akibatnya kemampuan membunuh jamur ini juga lebih rendah.

Penambahan tepung jangkrik pada media SDB meningkatkan virulensi $B$. bassiana. Konsentrasi tepung jangkrik yang optimum diberikan pada media pembiakkan $B$. bassiana adalah $0,5 \%$ karena pada konsentrasi tersebut mortalitas larva $P$. xylostella paling tinggi. Peningkatan virulensi $B$. bassiana karena penambahan tepung jangkrik merangsang B. bassiana menghasilkan enzim protease. Hal ini disebabkan tepung jangkrik mengandung kutikula serangga yang mampu merangsang pembentukan protease. Vey \& Fargues (1977) melaporkan enzim protease yang tinggi dapat mempercepat degradasi kutikula serangga inang sehingga $B$. bassiana lebih mudah masuk ke rongga tubuh serangga dan lebih cepat mematikan. Samsinakova et al. (1971) juga melaporkan $B$. bassiana mampu menghasilkan enzim 
khitinase yang mampu mendegradasi khitin. Karena tepung jangkrik pada penelitian ini berasal dari jangkrik yang masih hidup dan mengandung khitin dan protein yang berasal dari integumennya, maka khitinase akan lebih banyak diproduksi pada media diberi tepung jangkrik dibandingkan pada media tanpa tepung jangkrik. Dengan demikian, peningkatan virulensi $B$. bassiana yang dibiakkan pada media SDB yang diberi tepung jangkrik disebabkan adanya peningkatan enzim protease dan khitinase yang mampu mendegradasi kutikula dan khitin serangga inang sehingga lebih mudah menginvasi tubuh dan mematikannya.

\section{SIMPULAN}

Kerapatan spora B. bassiana pada media SDB yang tidak diperkaya dengan tepung jangkrik terus menurun bila subkultur terus dilakukan, namun pada media yang ditambah tepung jangkrik terjadi peningkatan kerapatan spora B. bassiana. Subkultur secara nyata dapat menurunkan viabilitas spora B. bassiana yang dibiakkan hanya pada media SDB yang tanpa diperkaya dengan tepung jangkrik. Selama dilakukan subkultur, virulensi $B$. bassiana yang dibiakkan pada media SDB tanpa tepung jangkrik cenderung terus menurun dibandingkan pada media SDB yang diperkaya dengan tepung jangkrik. Dengan demikian, pengayaan media dapat menstabilkan kualitas spora dan virulensi $B$. bassiana selama subkultur dilakukan.

\section{SANWACANA}

Penelitian ini merupakan bagian dari riset yang didanai oleh Proyek Riset Unggulan Terpadu (RUT) X Tahun Ke-2, Kementerian Riset dan Teknologi, Republik Indonesia dengan kontrak No. 14.40/SK/RUT/2004， 29 Januari 2004 a.n. Siti Herlinda.

\section{DAFTAR PUSTAKA}

Alberts B., D. Bray, L. Julian, M. Raff, K. Roberts, J.D.Watson. 1994. Biologi Molekuler Sel. Edisi ke-2. Alih Bahasa: A.T. Kantjono W. Jakarta: Penerbit PT Gramedia Pustaka Utama.
Fernandez, G.C.J. 2000. Design and analysis statistical methods using SAS macros. Http: //www.ag.unr.edu/gf.

Gabriel B.P. \& Riyatno. 1989. Metarhizium anisopliae (Metch) Sor: Taksonomi, Patologi, Produksi dan Aplikasinya. Jakarta: Direktorat Perlindungan Tanaman Perkebunan, Departemen Pertanian.

Magan, N. 2001. Physiological approaches to improving the ecological fitness of fungal biocontrol agents. Di dalam: Butt LM, Jackson CW, Magan N (ed). Fungi as Biocotrol Agents: Progress, Problem and Potential. UK: Biddles Ltd, Guildford and King's Lynn. hlm239-252.

Rasminah, S., S. Santoso \& Y. Ratna. 1997. Kajian kualitas spora Beauveria bassiana pada berbagai jenis media (PDA, jagung, alioshina) dan lama penyimpanan. Di dalam: Prosiding Kongres Nasional XIV dan Seminar Ilmiah Perhimpunan Fitopatologi Indonesia. Palembang, 27-29 Oktober 1997. hlm. 310-315.

Rosalind, R. 2000. The Effect of Certain Nutrients on Conidial Germination of Beauveria bassiana and Paecilomyces jumosoroseus. USDA: Agricultural Research Service, Tektran.

Samsinakova, A., S. Misikova, J. Leopold. 1971. Action of enzymatic system of Beauveria bassiana on cuticle of the greater wax moth larvae (Galleria mellonella). J. Invert. Pathol. 18:322-330.

Soetopo, D. 2004. Efficacy of selected Beauveria bassiana (Bals.) Vuill. isolates in combination with a resistant cotton variety (PSB-Ct 9) againts the cotton bollworm, Helicoverpa armigera (Hübner) (Lepidoptera: Noctuidae). [Disertasi]. Philippines: University of The Philippines Los Banos. 
Suharto, E.B., Trisusilowati \& H. Purnomo. 1998. Kajian aspek fisiologik Beauveria bassiana dan virulensinya terhadap Helicoverpa armigera. J. Perlin. Tan. Indonesia. 4:112119.

Taborsky, V. 1997. Small Scale Processing of Microbial Pesticides. Prague, Czechoslovakia: University of Agriculture.

Tanada Y. \& H.K. Kaya. 1993. Insect Pathology. New York: Academic Press.
Utomo, C.D, D. Pardede \& A. Salam. 1998. Beauveria sp. parasit pada larva penggerek batang kakao Zeuzera coffeae Nient. Buletin Perkebunan 19:137-142.

Vey, A. \& J. Fargues. 1977. Histological and ultrastructural studies of Beauveria bassiana infection in Leptinotarsa decemlineata larvae during ecdysis. J. Invert. Pathol. 30:207-215.

Wahyudi, P. 2002. Uji patogenitas kapang entomopatogen Beauveria bassiana Vuill. terhadap ulat grayak (Spodoptera litura). Biosfera 19:1-5. 